\title{
PERKEMBANGAN PENTADBIRAN TANAH DI KEDAH, 1909-1917
}

\author{
Nurizwanfaizi Nordin \\ Ahmad Kamal Ariffin Mohd Rus
}

\begin{abstract}
This study is an effort to explain the development of land administration in Kedah in the period 1909 to 1917. British control over Kedah through the Bangkok Treaty of 1909 brought about a significant impact on Kedah land administration. The British, in an aggressive manner, reorganised, reformed, and complemented the Kedah land administration. This act covered all aspects of land bureaucracy and law. Therefore, the main question examined in this study is the extent to which development in Kedah land administration succeeded in creating a modern land bureaucracy in the state. This article uses the historical analysis method to examine the primary soures related to land administration in Kedah. Based on these sources, the Kedah land administration was found to have modernised within a short period. However, this modernisation was based on a capitalist economic motive with the introduction a system of collection of land revenue to generate state revenue. This led to an imbalance transformation and did not provide providing full benefits to all parties.
\end{abstract}

\section{Pengenalan}

Penguasaan British di Kedah secara rasmi bermula apabila Perjanjian Bangkok ditandatangani antara Great Britain dan Siam di Bangkok pada 10 Mac 1909. Artikel pertama dalam perjanjian ini menyebut Kerajaan Siam memindahkan kepada British "semua hak naungan, perlindungan, pentadbiran dan kawalan yang dimiliki oleh mereka ke atas Negeri Kelantan, Terengganu, Kedah, Perlis dan pulau-pulau sekitarnya." 
Perjanjian ini diratifikasi pada Jun $1909 .{ }^{1}$ Pengambil alihan naungan British ke atas Kedah menggantikan Siam ini menjadi suatu titik tolak penting terhadap sistem pentadbiran Kedah.

Langkah awal British bagi menguatkuasakan naungan ke atas Negeri Kedah adalah menempatkan seorang pegawai berstatus Penasihat British yang berperanan menasihati Kerajaan Kedah dalam pelbagai aspek pentadbiran negeri. Tugas penting yang terbeban di bahu Penasihat British ialah merombak dan menguatkan sistem pentadbiran Kedah dan mengawal sistem kewangan negeri. Walaupun sehingga tahun 1923 tiada perjanjian rasmi yang konkrit antara Kerajaan Kedah dan Kerajaan British berhubung tugas Penasihat British yang dihantar berkhidmat dengan Kerajaan Kedah, Penasihat British nampaknya tidak berlengah-lengah untuk membuat perubahan dalam sistem pentadbiran Kedah. Bagi mewujudkan sebuah kerajaan yang mempunyai apparatus yang moden, peningkatan dalam aspek perolehan kewangan merupakan sesuatu yang penting. ${ }^{2}$ Antara bidikan utama British pada permulaan penguasaannya ke atas Kedah ialah sistem tanah dan perundangannya. Ini kerana, tanah merupakan salah satu faktor ekonomi yang sangat penting dalam sesebuah masyarakat. ${ }^{3}$

\section{Keadaan Pentadbiran Tanah Kedah Ketika Permulaan Penguasaan British}

Sebenarnya Kedah sudah mempunyai sebuah Jabatan Tanah yang tersendiri ketika ini. Juga sudah wujud Jabatan Tanah dan Pejabatpejabat Tanah di peringkat daerah. Sungguhpun asas kepada pentadbiran tanah moden sudah wujud sebelum penguasaan British, birokrasi tanah Kedah ini tidak dapat menjalankan fungsi sebenarnya dengan sempurna dan berkesan kerana masih wujud kuasa tradisional tempatan iaitu pemegang-pemegang mukim yang berkuasa mengutip cukai di kawasan yang dikurniakan Sultan kepada mereka. Begitu juga dengan masih wujud sistem tradisional masyarakat Melayu iaitu sistem kerah. Sistem Kerah ini menjadi penghalang terbesar kepada pengutipan cukai tanah ke atas rakyat Kedah. Dalam sisi perundangan pula, Kedah sudah pun memiliki set undang-undang tanah yang boleh dikatakan sebagai moden. Enakmen tanah yang digubal oleh Penasihat Kewangan Siam pada tahun 1906 iaitu Enakmen Tanah 1324 Hijrah (1906 Masihi) mempunyai ciri-ciri perundangan tanah yang moden. Malangnya Enakmen ini belum diperkenankan Sultan Abdul Hamid. Justeru, pentadbiran tanah sebelum 1909 ini hanya mengikut undangundang tanah ini dalam batasan-batasan yang begitu terhad.

Pada permulaan kedatangan George Maxwell bagi memangku jawatan Penasihat British ke Kedah, beliau melaporkan Kedah sudah 
memiliki pejabat-pejabat tanah yang bertaburan di seluruh negeri. Pejabat Tanah utama yang sekaligus berfungsi sebagai ibu pejabat pentadbiran tanah Kedah terletak di Alor Setar. Ibu Pejabat Tanah ini berada dalam kawalan langsung Kepala Pekerjaan Tanah, Syed Mansur Aljaffri. ${ }^{4}$ Maxwell juga melaporkan terdapat cawangan Pejabat-pejabat Tanah di setiap daerah, kecuali Daerah Padang Terap. Menurut Maxwell lagi, Pejabat-pejabat Tanah yang berada di bawah tanggungjawab Pegawai Tanah ini tidak dikendalikan dengan baik. ${ }^{5}$ Walaupun Jabatan Tanah merupakan pentadbiran dominan kepada hampir segenap urusan melibatkan tanah, namun urusan yang berkaitan tanah masih dibantu dan tidak dapat dipisahkan kebergantungannya kepada kerja ukur tanah yang dilaksanakan oleh Jabatan Ukur. Sekitar 1909-1910, Jabatan Ukur masih merupakan cabang daripada Jabatan Tanah. Maxwell melaporkan bahawa ibu pejabat Jabatan Ukur di Alor Setar mengandungi dua atau tiga kakitangan yang mempunyai pengetahuan menggunakan theodolite, manakala kakitangan selebihnya merupakan demaractors yang bekerja menggunakan kompas prismatik. Manakala semua Pejabat Tanah di seluruh Kedah terdapat demarcators. ${ }^{6}$

Berkenaan soal tanah lombong pula, pengurusan sektor perlombongan menjadi cabang yang terpisah dengan Jabatan Tanah Kedah sejak tahun 1907 lagi. Semenjak pengunduran Supritendan Lombong lantikan Kerajaan Siam iaitu F. P. Clark, Inspektor Lombong, Che Kassim bertindak memangku jawatan Supritendan Lombong. Di bawah tanggungjawab beliau ialah tujuh orang renjer lombong. Berkenaan aspek undang-undang tanah lombong, Kedah sudah memiliki perundangan berkenaan tanah lombong lama sebelum penguasaan British lagi iaitu Enakmen Perlombongan (Mining Enactment) yang diluluskan pada tahun 1885 dan enakmen tambahan yang telah diluluskan pada tahun 1902. Sungguhpun demikian, kedua-dua enakmen ini masih asas sifatnya. ${ }^{7}$ Dalam soal pentadbiran tanah hutan, masih belum wujud Jabatan Perhutanan pada tahun 1909-1910 bagi menguruskan soal perhutanan. Kedah hanya memiliki beberapa orang renjer hutan yang bertugas di Pejabat-pejabat Daerah di bawah kawalan atau seliaan yang minima. Sektor pengurusan hutan ini kemudian menjadi pertimbangan pihak British yang bertujuan mengawal sumbersumber hutan dan penggunaan tanah hutan. Walaupun pada 1909-1910 belum wujud Jabatan Perhutanan, soal pengurusan hutan mendapat perhatian serius pihak British. Selanjutnya, Enakmen Perhutanan dan Kayu Balak (Timber and Forest Enactment) dibincangkan di Majlis Negeri $(\mathrm{MN})$ bagi mengeluarkan suatu peraturan berhubung operasi pemungut hasil keluaran hutan. ${ }^{8}$ 


\section{Langkah-langkah Perubahan Pentadbiran Tanah}

\section{Pemansuhan Pemegang Mukim dan Sistem Kerah}

Menurur Peter Dorner dalam masyarakat bukan industri, tanah merupakan lambang kemewahan, sumber utama ekonomi dan kuasa politik. ${ }^{9}$ Jesteru, dalam masyarakat Melayu tradisional, tanah menjadi alat golongan elit untuk menguasai dan mengawal masyarakat kebanyakan. Di Kedah, ramai elit Melayu sebelum penguasaan British memiliki mukim sendiri dan mereka berkuasa dalam hal ehwal tanah dalam mukim pegangan mereka. Ini termasuklah hal ehwal percukaian tanah. Sistem kerah pula menjadi instrumen elit Melayu untuk menggembeleng tenaga manusia untuk mengerjakan tanah yang dimiliki dalam tempoh tertentu setiap tahun. Sistem ini dikenakan ke atas rakyat biasa dalam kalangan masyarakat Melayu. ${ }^{10}$ Namun, rakyat yang membayar cukai tanah dikecualikan daripada kerja kerah. Bagaimanapun, selepas 1909 demi memastikan aspek berkaitan tanah dipusatkan di bawah satu autoriti sahaja, MN mengambil langkah awal menyelesaikan dua perkara berkenaan. Kedua-dua perkara ini sangat penting kepada kerajaan kerana ini melibatkan aspek pencukaian tanah. Sistem ini juga menjadi faktor penyebab kutipan cukai tanah dan sewa tanah tidak dapat dijalankan dengan sistematik. Kewujudan pemegang mukim dan sistem kerah ini tidak memberikan sumbangan yang berkesan kepada kemajuan Kedah mahupun sistem kewangannya. Ini kerana amalannya lebih bersifat eksploitatif dan menguntungkan segelintir kelas pemerintah Melayu Kedah, bukannya pentadbiran pusat di Alor Setar.

Pemansuhan pemegang mukim dilaksanakan dengan cepat apabila pada Oktober 1909, suatu proklamasi berkenaan dengannya ditandatangani oleh Sultan Abdul Hamid. Pemegang mukim kehilangan kuasa terhadap mukim-mukim mereka. Kedudukan penghulupenghulu mukim yang selama ini bertanggungjawab kepada pemegang mukim juga diberikan perhatian yang serius oleh pihak kerajaan. Majlis Negeri (MN) mengambil keputusan untuk membayar gaji kepada para penghulu. Penghulu-penghulu baru dilantik dengan syor dan sokongan Pegawai Daerah. Pelantikan penghulu-penghulu baru dan bergaji menggantikan mereka yang tidak bersesuaian telah memutuskan hubungan penghulu-penghulu dengan pemegang mukim. Penghulu kini dianggap sebagai kakitangan kerajaan. Kerajaan juga berjaya mengambil alih semua terusan yang dimiliki keluarga elit Melayu tradisional demi memusatkan pentadbiran dan pencukaian tanah ke tangan kerajaan. Terusan terakhir yang diambil alih ialah Terusan Wan Yunus. ${ }^{11}$ 
Sistem kerah merupakan sistem yang kuat dipertahankan Sultan Abdul Hamid. Tidak semudah pemansuhan pemegang mukim, pihak kerajaan sukar untuk meyakinkan Sultan untuk memansuhkannya. Sultan memandang sistem kerah ini sebagai prerogatif diraja. Pandangan ini berbeza dengan pendirian keseluruhan anggota MN yang dilaporkan Maxwell, sebagai tidak bersetuju dengan kewujudannya. Sistem kerah ini membebankan pentadbiran tanah Kedah kerana wujudnya pilihan kepada rakyat sama ada melaksanakan kerah atau membayar cukai. Kerumitan-kerumitan yang dibawa oleh sistem ini ialah pertama, kerajaan terpaksa menjalankan penyiasatan yang teliti sebelum boleh menerima tender untuk pembayaran cukai ekoran kebimbangan wujud rakyat yang melakukan penipuan bagi mengelak kerja kerah. Kedua, senarai pengecualian yang luar biasa jumlahnya diakibatkan oleh senarai pendaftaran pemilikan yang tidak kemas, dan ketiga tiada mekanisme untuk memaksa pembayaran sewa tanah dan Pegawai Tanah hanya boleh selepas pengeluaran notis pembayaran, untuk menyaman berkenaan jumlah tunggakan hutang di Mahkamah Daerah. ${ }^{12}$

Selain faktor kemanusiaan yang dibawa British, sistem kerah ini seperti yang dinyatakan sifatnya menjadi batu penghalang kepada kemajuan pemodenan pentadbiran tanah. Dua atau tiga percubaan dilaporkan bagi memujuk Sultan Abdul Hamid supaya memansuhkan sistem ini. Bagaimanapun, Sultan Abdul Hamid terus menganggap sistem ini merupakan sebahagian daripada hak-hak istimewa diraja dan membantah keras terhadap percubaan menggugat kewujudannya. Tidak berputus asa, pada pertemuan MN pada 23 Ogos 1909, Auditor General, Syed Muhammad Shahabudin mencadangkan supaya sistem ini dihapuskan. Saranan beliau ini mendapat sokongan sebulat suara anggota MN. ${ }^{13}$ Beberapa hari kemudian, semua anggota $\mathrm{MN}$ menghadap Sultan Abdul Hamid dan berjaya memujuk baginda memansuhkan sistem ini. ${ }^{14}$ Akhirnya pada 25 Oktober 1909 Sultan Abdul Hamid berkenan menandatangani proklamasi memansuhkan sistem kerja kerah di seluruh Kedah berkuatkuasa pada 30 Oktober. Pengisytiharan ini dicetak dan war-warkan di tempat-tempat awam termasuk di masjid. Maxwell percaya pengisytiharan ini akan membawa kesan baik kepada Kedah. ${ }^{15}$ Beliau menyatakan pandangan gembiranya ekoran pemansuhan sistem kerah dengan menyatakan:

It was, of course, welcomed everywhere. The effect of this important step cannot, I think, fail to have the most beneficial results, not only in setting the Malay agricultural class free from oppression, but in adding to the land revenue and in attracting immigration. ${ }^{16}$ 
Kejayaan memujuk Sultan Abdul Hamid menghapuskan sistem kerah diikuti oleh kejayaan pengabsahan Enakmen Tanah 1324 Hijrah (1906). Ini kerana selepas Sultan Abdul Hamid menandatangani proklamasi 25 Oktober 1909, Maxwell tidak mempunyai sebarang masalah bagi memujuk Sultan Abdul Hamid menandatangani Enakmen Tanah 1324 Hijrah (1906) yang sebelum ini enggan diabsahkan. ${ }^{17}$ Pemansuhan pemegang mukim dan sistem kerah menghapuskan halangan terbesar kerajaan untuk memodenkan sistem pentadbiran tanah Kedah.

\section{Reformasi Sistem Pentadbiran Tanah Kedah}

Disebabkan sistem pendaftaran tanah Kedah masih dalam keadaan asas, pada November 1910, MN memutuskan untuk memohon kepada Pesuruhjaya Tinggi British untuk mendapatkan perkhidmatan seorang pegawai bagi ditempatkan di Pejabat Tanah untuk tempoh enam tahun bagi tujuan memperkenalkan sistem yang sama yang dijalankan di Negeri-negeri Melayu Bersekutu (NNMB) dan bagi memberikan nasihat berkaitan hal ehwal pentadbiran tanah dan rutin-rutinnya. Tahun 1911 menyaksikan Penasihat Tanah Kedah yang pertama iaitu G. E. Shaw yang dipinjamkan NNMB untuk menasihati Jabatan Tanah. Beliau dihantar ke Kedah atas permintaan khas MN untuk tempoh masa yang tidak ditentukan. Shaw menjalankan tugas di Kedah bermula pada 14 Mei 1911.

Penasihat Tanah sangat berpengaruh dalam mencorak dasardasar tanah Kedah. Peranan yang dimainkan oleh Penasihat Tanah boleh dibahagikan kepada tiga tugas utama iaitu pertama, merangka dasar-dasar tanah, kedua memantau dan ketiga, menyelia pentadbiran harian Jabatan Tanah. Selain itu, Penasihat Tanah juga menjadi rujukan utama pentadbiran tanah Kedah dalam memastikan kelancaran pentadbiran tanah. Urusan 'penasihatan' oleh Penasihat Tanah ini sebenarnya berlangsung dalam suasana yang harmonis antara kakitangan-kakitangan Melayu sepanjang tempoh 1909-1941. Dengan agresif, Shaw telah berjaya mendraf beberapa enakmen iaitu Enakmen Persempadanan (Boundaries Enactment), Peraturan Jabatan Kepada Pegawai-pegawai Tanah (Departmental Instructions to Land Officers), Enakmen Pemilikan Tanah (Land Titles Enactment) dan Enakmen Perlombongan (Mining Enactment) sebelum berakhir tahun 1911. ${ }^{18}$

MN juga secara serius membuat pertimbangan bagi mencari jalan yang terbaik bagi membentuk Jabatan Ukur yang efisyen. Jabatan Ukur yang masih merupakan sebahagian cabang pentadbiran tanah, mempunyai seramai 38 orang "kakitangan persempanan" dan enam draughtsmen dan beberapa orang pengesan yang mempunyai sedikit pengetahuan asas mengenai kerja-kerja yang dijalankan. Soal ukur 
merupakan isu yang sangat penting kepada kelancaran pentadbiran tanah itu sendiri kerana Jabatan Ukur bertanggungjawab mengukur dan menetapkan sempadan pendudukan tanah. Penetapan ini akan membolehkan dokumen pemilikan dikeluarkan dan dengan kewujudan dokumen-dokumen hak milik tanah inilah cukai dapat dikutip dan menghindarkan sebarang pertindihan pemilikan dan pertelingkahan di masa hadapan.

R.W.B. Darke daripada Jabatan Ukur NNMB tiba di Kedah pada bulan November 1909 untuk melihat dan mengulas mengenai sistem ukur Kedah. Pada Julai 1910, MN meluluskan laporan dan syor-syor yang dikeluarkan oleh Darke. ${ }^{19}$ Pada masa yang sama, MN memutuskan untuk memohon supaya Darke ditukarkan ke perkhidmatan awam Kedah sebagai Supritendan Ukur. Permohonan Kedah ini diluluskan oleh Pemangku Raja dan Pesuruhjaya Tinggi. Hasilnya Darke memulakan tugas beliau di Kedah pada 8 Ogos 1910. Ketika inilah berlaku pemisahan antara Jabatan Tanah dan Jabatan Ukur. Pemisahan ini bagaimanapun tidak merencatkan kerja-kerja kedua-dua jabatan ini, sebaliknya merancak dan melicinkan proses pembaharuan sistem tanah Kedah. Di bawah sistem baru yang diperkenalkan oleh Darke, terdapat dua perbezaan kakitangan kerja ukur di lapangan iaitu kakitangan Persempadanan yang bertanggungjawab kepada Kepala Pekerjaan Tanah serta tidak bertanggungjawab kepada Jabatan Ukur dan kakitangan Ukur yang bertanggungjawab kepada Supritendan Ukur dan tidak mempunyai kaitan dengan Pejabat Tanah.

\section{Pengukuran Dan Pengeluaran Dokumen Pemilikan Tanah}

R.W.B. Darke telah membawa pembaharuan dalam proses pengukuran dan pengeluaran dokumen pemilikan tanah. Persempadanan dan pengukuran tanah merupakan dua perkara yang sangat penting dalam membicarakan proses pemberian pemilikan tanah. Dua badan utama yang bertanggungjawab langsung dalam soal ini ialah Jabatan Tanah dan Jabatan Ukur. Proses penentuan sempadan (perenggan) tanah dijalankan pihak Pejabat Tanah melalui kakitangan persempadanan. Kakitangan persempadanan bertanggungjawab mengesahkan sempadan pemegangan tanah lama dan baru dibuka. Setiap kakitangan persempadanan di daerah-daerah bertanggungjawab kepada Pegawai Persempadanan (Boundary Officer). Pegawai Persempadanan ini pula bertanggungjawab secara langsung kepada Pegawai Tanah Daerah. Pegawai Persempadanan bertanggungjawab memberi tugasan kepada setiap kakitangan persempadanan. Tugasan kakitangan persempadanan dapat dibahagikan kepada empat tugas penting iaitu: 
i. Menetapkan perenggan-perenggan konsesi baru yang telah diluluskan oleh MN, dan meletakkan batu-batu penanda perenggan tanah.

ii. Menetapkan perenggan pada mana-mana tanah di bawah geran tanah lama dan meletakkan batu-batu perenggan. Tugas ini akan dijalankan sekiranya pemilik tanah mahu sempadan tanah mereka ditentukan dan telah membayar deposit bagi upah kerja-kerja ukur.

iii. Meletakkan batu-batu perenggan bagi pemilikan ke atas tanahtanah berkeluasan kecil dan berhampiran antara satu sama lain.

iv. Dari masa ke masa menanda pemilikan tanah berkeluasan kecil dan meletakkan batu-batu perenggan. (sebagai peraturan, tugas ini dijalankan oleh penghulu).

Dalam setiap kes, Pegawai Persempadanan atau pembantunya perlu menyiasat perenggan-perenggan tanah beserta batu-batu perenggan. Sekiranya terdapat sebarang masalah pertikaian perenggan tanah, Pegawai Persempadanan bertanggungjawab menjalankan tindakan serta merta untuk membuat keputusan segera berhubung isu tersebut. Kegagalan membuat keputusan akan menyebabkan kes tersebut diaju dan diputuskan di mahkamah. Keberhasilan Pegawai Persempadanan menentukan persempadanan tanah sebagai benar dan bebas daripada sebarang pertikaian akan membolehkan beliau mengajukan lakaran persempadan yang telah dibuat melalui Pegawai Tanah. Setelah diteliti perakuan akan dilakukan oleh Pegawai Tanah. Langkah seterusnya ialah lakaran persempadan tanah tersebut akan diajukan kepada Pejabat Ukur bersama-sama permohonan sukat. Proses menyukat tanah yang teliti akan mengambil masa yang lama. Oleh itu, kerajaan akan mengeluarkan 'geran sementara' atau lebih dikenali sebagai Surat Kechil atau Surat Putus Kechil (Provisional Grant) bagi kes (i), (ii), dan (iv) dan geran ini bergantung kepada pelan dan perakuan daripada Pegawai Persempadanan.

Surat Kechil ini akan memberikan hak-hak kepada pemilik tanah terhadap tanah yang terkandung dalam dokumen pemilikan tersebut. Kelemahan geran sementara ini ialah kawasan tanah yang ditentukan tidak tepat sepenuhnya. Geran sementara ini perlu diserahkan kembali apabila tanah selesai diukur oleh Jabatan Ukur dan semua bayaran berkaitan perlu dilunaskan termasuk (sewa, premium dan kos ukur) apabila geran pemilikan tanah akhir iaitu Surat Putus dikeluarkan. Kecekapan sistem pemberian pemilikan tanah ini diulas oleh Penasihat British, George Maxwell pada 1328 Hijrah (1910): 
It will be seen that under this system the government, in dealing with applications for land, is able, not only to cut out the block applied for, but to issue a negotiable title for it, in a very short time. ${ }^{20}$

Di bawah sistem ini, terdapat garis panduan khusus kepada juru ukur berlesen persendirian sekiranya mana-mana syarikat pelabur mahu mendapatkan khidmat juru ukur berlesen. Darke sendiri telah menggariskan beberapa panduan yang harus diikuti oleh juru ukur berlesen. Namun demikian, keputusan ukur akhir berkenaan hasil pengukuran berkenaan terletak di tangan Kerajaan Kedah. ${ }^{21}$ Kehadiran Darke benar-benar mengubah wajah Jabatan Ukur Kedah daripada sebuah jabatan yang kecil kepada sebuah jabatan yang cekap dan mempunyai kakitangan yang bermutu. ${ }^{22}$

\section{Usaha Awal Pemberian Pemilikan Tanah}

Soal pemberian pemilikan tanah juga menjadi agenda penting kerajaan. Agenda ini mampu diibaratkan sebagai langkah serampang dua mata kerana mempunyai dua tujuan. Tujuan pertama ialah pemberian pemilikan tanah berkeluasan besar untuk faedah pelaburan dan kedua pemberian pemilikan tanah berkeluasan kecil melalui dokumen pemilikan yang sah kepada rakyat sekaligus memudahkan kutipan cukai tanah dikenakan. Oleh yang demikian, Enakmen Konsesi diluluskan untuk memberikan justifikasi yang jelas mengenai pemilikan tanah berkeluasan besar. Penguatkuasaan enakmen ini tentunya nyata disasarkan kepada pemodal-pemodal asing yang mula merebut peluang memiliki tanah pertanian khasnya di Kedah Selatan. Memandangkan sebelum ini Surat Putus dikeluarkan kerajaan tanpa sebarang garis panduan yang rigid, Enakmen Konsesi ini memberi panduan kepada pentadbiran tanah Kedah dalam menguruskan pemberian tanah yang berkeluasan besar (melebihi 50 relong). ${ }^{23}$ Perlaksanaan Enakmen Konsesi ini juga memberikan garis panduan jelas antara pelabur dan kerajaan dalam mengendalikan soal tanah yang diusahakan.

Setelah menetapkan kaedah dan prosedur pengukuran tanah dan pemberian tanah berkeluasan besar kepada para pelabur. MN pada tahun 1911 beralih pula kepada soal pemilikan tanah orang Melayu. Bagi mencegah dan menetapkan undang-undang mengenai pendudukan tanah secara tidak sah oleh orang Melayu, Enakmen Pas-pas Pendudukan 1329 Hijrah (The Squatters' Passes Enactment 1329) (1911) dan Enakmen Ladang 1329 Hijrah (The Ladang Enactment 1329), (1911) berkaitan penanaman padi huma diluluskan MN. ${ }^{24}$ Penting dinyatakan di sini bahawa menjelang penguasaan British di Kedah, terlalu ramai orang Melayu yang menduduki tanah-tanah tanpa sebarang dokumen pemilikan yang sah. Begitu juga dengan 
pengusahaan tanaman padi huma telah dijalankan secara berleluasa tanpa sebarang sekatan. Sehubungan itu, dibangkitkan dalam MN mengenai pendudukan di tanah kerajaan oleh mereka yang tidak mempunyai sebarang dokumen untuk menyokong pendudukan mereka ke atas tanah tersebut. Pada Mac 1912, MN telah meluluskan peraturan berkenaan permohonan tanah berkeluasan kecil (tanah rinchek-rinchek). Peraturan ini dikuatkuasakan dalam tempoh percubaan sehingga akhir tahun. MN juga memutuskan sebarang aduan atau maklum balas daripada rakyat Kedah berhubung perlaksanaan peraturan ini dan akan mempertimbangkannya. ${ }^{25}$

Hasilnya, MN membuat keputusan meminta Kepala Pekerjaan Tanah untuk mengeluarkan notis am kepada mereka yang berkenaan untuk mendapatkan dokumen pemilikan tanah daripada Jabatan Tanah. Mereka yang berada dalam lingkungan tujuh batu dari Pejabat Tanah dibenarkan tempoh dua bulan untuk berbuat demikian dan mereka yang di luar jarak tersebut selama empat bulan. Selepas tempoh tersebut, bagi mereka yang menduduki tanah tanpa dokumen pemilikan, Kepala Pekerjaan Tanah akan mengambil tindakan tegas terhadap mereka di bawah seksyen 8 Enakmen Pas-pas Pendudukan 1329 Hijrah (1911) ${ }^{26}$

\section{Rombakan Tugas Jabatan Tanah}

Selain kurang mempunyai kakitangan yang berpengalaman, Jabatan Tanah Kedah juga terpaksa menanggung bebanan masalah yang rumit berhubung transaksi melibatkan tanah. Demi melancar dan melicinkan jentera pentadbiran tanah Kedah, Kerajaan Kedah atas nasihat British telah menggubal empat undang-undang kecil berhubung transaksi tanah. Enakmen Pendaftaran dan Penggadaian (Tanah) 1331 Hijrah (1912-1913) (Registration of Sales and Mortages (Land) Enactment, 1331) (1912-1913) diluluskan bagi memudahkan pentadbiran dalaman Jabatan Tanah. Sebelumnya semua dokumen seperti bil of sale, semua jenis kontrak, kuasa guaman dan sebagainya didaftarkan di Pejabat Tanah. Tugas pendaftaran ini mengambil banyak masa para Pegawai Tanah bersama-sama pihak yang terlibat, keperluan mereka untuk hadir ke mahkamah, serta tugas-tugas lain yang tiada kaitan langsung dengan pentadbiran tanah. Enakmen ini dilaporkan telah dilaksanakan dengan baik, difahami ramai dan dirujuk kepada para Pegawai Tanah. Pengenalan Enakmen Pemindahan Pemilikan 1331 Hijrah (Bills of Sales Enactment 1331) (1912-1913) dan Enakmen Pendaftaran Dokumen 1331 Hijrah (Registration of Documents Enactment, 1331) (1912-1913) membolehkan tugas-tugas yang dijalankan oleh Pegawai Tanah diserahkan kepada pihak Mahkamah dan Perbendaharaan Negeri. Pada masa yang sama, kualiti kerja kakitangan Pejabat Tanah meningkat 
dan Pegawai Persempadanan dilaporkan oleh Penasihat Tanah, G.E. Shaw sebagai melakukan tugas dengan baik dan di luar jangkaannya. Pada tahun 1912-1913, Kerajaan Kedah bertindak meluluskan beberapa undang-undang yang membantu melancarkan operasi Jabatan Tanah yang mencakupi sudut perizaban tanah serta penggunaan tanah iaitu Enakmen Rizab Tanah (The Land Reserves Enactment) dan Enakmen Pengambilalihan Tanah Untuk Tujuan Awam (The Acquisition of Land for Public Purposes Enactment). ${ }^{27}$ Perizaban melibatkan sungai-sungai, jeram-jeram, saliran-saliran, lombong-lombong, dan mineral-mineral. Terdapat juga syarat untuk pembayaran sewa tanah tahunan, penyelenggaraan sempadan, pemberian dokumen pemilikan berkenaan dengan pembahagian tanah, soal kegunaan kerajaan bagi motif kepentingan kerja awam bagi membolehkan kerajaan membina longkang-longkang, talian telegraf dan sebagainya. ${ }^{28}$

\section{Penguatkuasaan Kutipan Cukai}

Soal kewajipan pemilik tanah melunaskan pembayaran cukai menerima perhatian yang rapi oleh pihak MN dan pentadbiran tanah. Pejabatpejabat Tanah di seluruh Kedah digesa untuk meningkatkan kecekapan pengutipan cukai tanah di kawasan tanggungjawab masing-masing. Kedah Selatan yang menjadi kawasan utama pertanian komersial di Kedah mendapat perhatian yang lebih daripada pihak kerajaan. Sebarang masalah kutipan cukai tanah di Kedah Selatan akan menggugat pendapatan kerajaan. Pada Januari 1912, Kepala Pekerjaan Tanah dan Auditor General melaporkan kepada MN mengenai kelemahan kutipan cukai tanah di Kedah Selatan disebabkan ketidakcekapan Pegawai-pegawai Tanah Daerah kecuali Daerah Kerian. MN mengambil keputusan melantik Penolong Kepala Pekerjaan Tanah bagi Kedah Selatan. Pegawai Daerah Kulim, Tunku Abaidah, dilantik ke jawatan ini. ${ }^{29}$ Sehingga tahun 1913, peruntukan berhubung pencukaian tanah dalam Enakmen Tanah Tahun 1324 Hijrah (1906) menjadi panduan dalam pengenaan cukai tanah kepada para pemilik. Pengukuhan sudut pencukaian tanah Kedah diperkemaskan lagi dengan pengenalan Enakmen Cukai Tanah Tahun 1331 Hijrah (The Land Tax Enactment 1331) (1913).

Enakmen Cukai Tanah ini memperbaharui dasar pencukaian yang ditentukan oleh Seksyen 21 Enakmen Tanah 1324 Hijrah (1906). Enakmen ini menyatakan bahawa Kerajaan Kedah perlu meningkat atau mengurangkan jumlah cukai tanah setiap lima tahun bagi tanah berkeluasan kecil (tidak melebihi 20 relong). Ia menetapkan kadar cukai bagi tanah berkeluasan kecil bagi semua jenis tanah. Kadar 50 sen serelong dikenakan kepada semua jenis tanah di daerah-daerah yang 
disenaraikan manakala kadar 30 sen bagi tanah sawah di daerah-daerah terpilih. Inti penting Enakmen Cukai Tanah 1331 Hijrah dapat dilihat dalam Perkara 1 dan Perkara 4. Perkara 1 telah menetapkan kerajaan pada 1334 Hijrah (1916) tidak boleh menaikkan cukai melebihi kadar 50 peratus. Menetapkan cukai tanah tidak melebihi 75 sen bagi jumlah 50 sen dan tidak melebihi 45 sen bagi kadar 30 sen. Manakala Perkara 4 menyatakan kadar yang ditentukan pada 1334 Hijrah (1916) perlu berkuatkuasa untuk tempoh 15 tahun. Selepas 15 tahun MN tidak boleh menaikkan cukai tanah melebihi kadar 50 peratus.

Pengecualian cukai bagaimanapun dinikmati oleh segelintir masyarakat Melayu yang terdiri daripada kerabat diraja dan pentadbirpentadbir tempatan. Ia merupakan legasi era tradisional kerana pada ketika itu kerabat diraja, elit Melayu, dan 'Orang Baik-baik' dikecualikan daripada membayar cukai dan melaksanakan kerah. Di era baru ini, seperti yang telah dinyatakan, hanya sistem kerah yang dihapuskan. Keistimewaan tertentu kerabat diraja dan elit tempatan masih dinikmati. Hal ini merupakan salah satu strategi pihak British menjaga hubungan mereka dengan golongan atasan Melayu Kedah. Sebenarnya, bahagian yang besar daripada kutipan cukai tanah yang boleh diperolehi perbendaharaan negeri daripada kerabat diraja Kedah dan elit Melayu, sekiranya tiada diskriminasi cukai berlaku. Pemberian pengecualian cukai ini seolah-olah sedikit kesinambungan amalan era tradisional. Bagaimanapun, Sultan tidak lagi mempunyai kuasa mutlak untuk memberikan pengecualian kepada sebarang individu yang dikehendaki. Kini kuasa untuk mengecualikan cukai tertakluk kepada keputusan MN.

\section{Pengenalan Enakmen Tanah Tahun 1332 Hijrah (1914)}

Pengenalan Enakmen Tanah Tahun 1332 Hijrah (1914) menjadi satu batu ukur penting dalam melihat perkembangan sistem pentadbiran tanah Kedah. Menggantikan Enakmen Tanah Tahun 1324 Hijrah (1906), enakmen baru ini menjadi sumber perundangan tanah yang buat pertama kalinya lengkap bagi Negeri Kedah. ${ }^{30}$ Berdasarkan Sistem Torrens, enakmen ini menguat dan memperkemaskan lagi sistem pendaftaran tanah sedia ada yang dimulakan Enakmen Tanah Tahun 1324 Hijrah (1906). ${ }^{31}$ Enakmen Tanah Tahun 1332 Hijrah (1914) ini merangkumi 11 bahagian iaitu tanah luar bandar yang tidak melebihi 50 relong, tanah luar bandar yang melebihi 50 relong, pajakan pertanian, tanah bandar, pas-pas tumpang, pas-pas ladang, rizab-rizab, transaksi melibatkan tanah dan prosedur kutipan cukai tanah.

Enakmen ini mewajibkan Surat Putus Lama dan Surat Kechil Lama perlu didaftarkan di Pejabat Tanah dalam tempoh enam bulan selepas 
tarikh kuatkuasa enakmen. Kelebihan yang terdapat pada enakmen baru ini secara langsung mampu memberikan sekuriti pemilikan tanah oleh pemilik dokumen tanah yang sah. Pembayaran cukai yang berterusan juga akan menjamin pemilikan individu ke atas tanah secara berterusan. Dalam soal perundangan dan keadilan, mahkamah menjadi medium untuk mendapatkan pertimbangan dan keputusan terhadap isu-isu melibatkan tanah yang berbangkit. Perkara 27 menetapkan MN sebagai kuasa tertinggi yang membuat pelbagai peraturan berkenaan prosedur berkaitan permohonan tanah. MN juga menurut enakmen ini, berkuasa dari masa ke masa menentukan kadar yuran ukur dan lain-lain bentuk bayaran di bawah enakmen ini. MN turut berkuasa menetapkan tugas dan bidang kuasa pegawai-pegawai Jabatan Tanah Kedah. Selain itu, bagi mengatasi Enakmen Tanah Tahun 1332 Hijrah (1914), MN berhak meminda mana-mana bahagian dan perkara berkaitan penguatkuasaan Enakmen Tanah Tahun 1332 Hijrah (1914) ini. ${ }^{32}$

Bahagian yang tidak kurang pentingnya dalam Enakmen Tanah Tahun 1332 Hijrah (1914) ialah penetapan kadar cukai tanah bagi jenis-jenis tanah yang dimiliki. Gesaan kepada pemilik tanah untuk mendapatkan dokumen pemilikan tanah yang terkini dapat dilihat melalui peruntukan dalam undang-undang tanah. Misalnya, pemilik tanah di bawah dokumen permit digesa untuk mendapatkan Surat Putus atau Surat Kechil sebagaimana terkandung dalam Perkara 34. Gesaan atau secara tersiratnya, paksaan ini kelihatan apabila Perkara 34 mengkehendaki pemegang permit membayar sewa tanah dalam kadar yang tinggi setiap tahun sehingga mereka mendapatkan Surat Putus atau Surat Kechil menggantikan permit yang dimiliki. ${ }^{33}$ Pajakan pertanian yang diberikan oleh Kerajaan Kedah ketika di bawah pertuanan Siam kepada pelabur Eropah turut disentuh dalam Enakmen Tanah Tahun 1332 Hijrah (1914). Pemilik pajakan perlu memohon semula kepada MN bagi menukarkan Pajakan mereka kepada Surat Putus. Pegawai Tanah Daerah perlu mengeluarkan pas kepada mana-mana individu yang menduduki tanah kerajaan atau tanah lombong untuk tempoh tidak melebihi satu tahun. Rakyat diwajibkan mengambil pas ladang bagi mengerjakan tanaman padi huma, jagung, tebu, tembikai, dan jenis-jenis tanaman pindah. Oleh itu, jelas sekali semangat enakmen ini antara lain mewajibkan setiap pendudukan manusia ke atas tanah didaftarkan di Pejabat Tanah dan pastinya kebenaran rasmi perlu diberikan Jabatan Tanah bagi kelangsungan pendudukan seseorang individu ke atas tanah.

Bahagian X Enakmen Tanah Tahun 1332 Hijrah (1914) menjadi komponen yang sangat penting dalam konteks penguatkuasaan kutipan cukai tanah di Kedah. Perkara ini menjelaskan dengan terperinci prosedur yang dilaksanakan Pejabat Tanah bermula dengan 
pengeluaran notis tuntutan cukai tanah, tempoh masa perlunasan cukai tanah dan akibat yang harus ditanggung pemilik tanah yang gagal melakukan pembayaran. Pemangku Penasihat British L. E. P. Wolfertan mengulas mengenai kepentingan Enakmen Tanah Tahun 1332 Hijrah (1914) dengan menyatakan:

Enactment 7 of 1332 marks an epoch in the recent history of land law in Kedah. The Land Enactment, 1324, which it repealed had been found as time progressed wanting in many respects, and a mass of conventions and precedents had been established to fill gaps and supplement the law. ${ }^{34}$

Undang-undang tanah ini dianggap sebagai kompilasi undangundang berkenaan tanah dan prosedur berkaitan yang diluluskan oleh MN selepas pemindahan naungan Kedah daripada Siam kepada British. ${ }^{35}$ Pihak British begitu berharap pengenalan enakmen baru ini akan membantu dan memudahkan transaksi perniagaan melibatkan tanah dan pada masa yang sama elastik kepada penambahbaikan dan pindaan-pindaan yang akan dilakukan dari masa ke masa. Dengan lulusnya enakmen ini juga, peluang diambil untuk merangkumkan beberapa peraturan berkaitan tanah sebelumnya berkenaan dengan pas pendudukan tidak sah, pas ladang, konsesi dan pendaftaran pemilikan tanah. $^{36}$

\section{Keberkesanan Perkembangan Pentadbiran Tanah Kedah Pemberian Pemilikan Tanah}

Penguasaan British di Kedah pada tahun-tahun awal tidak menyaksikan sebarang dasar pemberian tanah yang ketat. Mana-mana pihak mempunyai peluang untuk memohon tanah kerajaan yang diingini. Pada awal tahun, dasar tanah Kedah boleh dikatakan sebagai fleksibel dan bergantung sepenuhnya terhadap budi bicara pentadbiran tanah Kedah dan MN. Kerajaan Kedah melaksanakan dasar menggalakkan orang Melayu untuk mendapatkan dokumen pemilikan tanah yang sah bagi tanah-tanah yang diduduki. Orang Melayu boleh memiliki tanah berkeluasan kecil secara bebas dengan syarat melakukan pembayaran harga tanah dan kos-kos berkaitan pengukuran tanah. Manakala daripada sudut tanah komersial, Kerajaan Kedah mengalu-alukan kemasukan pelaburan asing dalam sektor pertanian. Pemberian tanah kepada golongan kapitalis ini bergantung sepenuhnya terhadap budi bicara MN. Meninjau minit-minit mesyuarat MN, lebih banyak agenda pemberian tanah kepada pemodal asing dibicarakan daripada isu pemberian pemilikan tanah kepada rakyat. Pemberian tanah pertanian kepada pelabur-pelabur asing secara aktif hampir keseluruhannya tertumpu di Kedah Selatan. Misalnya pada tahun 1331 Hijrah (1912), 
dilaporkan pemberian sebahagian besar daripada jumlah 5,731 relong tanah yang diberikan Pejabat-pejabat Tanah adalah di Kedah Selatan. Daripada jumlah tersebut, sebanyak 3,026 relong diberikan kepada pemohon di bawah Enakmen Konsesi. ${ }^{37}$

Sungguhpun pentadbiran tanah Kedah mempunyai sistem perundangan tanah yang baik menurut undang-undang tanah di NNMB, masih wujud kelemahan yang ketara dalam aspek jentera pentadbiran tanah. Ini kerana, kemajuan perundangan tanah Kedah tidak selari dengan peningkatan mutu kerja kakitangan Pejabatpejabat Tanah. Perbezaan kecekapan kerja juga jelas berlaku antara bahagian Kedah Utara dan Kedah Selatan. Kelemahan ini menyumbang kepada kurangnya kecekapan proses pemberian tanah kepada rakyat. Walaupun enakmen tanah moden telah dizahirkan pada tahun 1332 Hijrah (1914), sistem pemilikan tanah Kedah juga masih belum benarbenar tersusun. Ini diakui oleh Pemangku Penasihat British di Kedah pada tahun 1332 Hijrah (1913-1914) L.E.P. Wolferstan:

In Kedah at present an effort is made to follow the Federated Malay States system as far as new lands are concerned, but it is found difficult to discourage the present system obtaining here. There has been great neglect for a long period, and it is therefore difficult to put the title system in order. The main difficulty is the want of capable clerks and effective superintendence. ${ }^{38}$

Daripada sudut yang lain pula, kewujudan undang-undang tanah moden ini sedikit sebanyak membantu melancarkan proses pengelasan, pendaftaran dan pemberian tanah. Sebenarnya pihak British lebih memberikan perhatian kepada isu pemberian tanah berkeluasan besar iaitu melebihi 50 relong. Tarikan pelaburan asing yang besar di bahagian Kedah Selatan menyaksikan pertambahan jumlah permohonan tanah yang semakin besar saban tahun. Daerah Kuala Muda misalnya menerima jumlah permohonan tanah yang terbesar di Kedah pada tahun 1332 Hijrah (1913-1914).

Pada tahun 1332 Hijrah (1913-1914), terdapat lapan permohonan tanah berkeluasan melebihi 50 relong merangkumi keluasan keseluruhan sebanyak 1,334 relong. Daripada jumlah ini empat permohonan tanah diluluskan Kerajaan Kedah. Sebanyak 1,036 permohonan tanah berkeluasan kecil diterima melibatkan kawasan seluas 3,276 relong. Jumlah permohonan tanah berkeluasan melebihi 50 relong terus bertambah pada tahun 1333 Hijrah (1914-1915) apabila sembilan permohonan diterima melibatkan keluasan keseluruhan 8,264 relong. Di Kedah Utara, sebanyak 1,839 Surat Kechil dan Permit dikeluarkan, manakala di Kedah Selatan pula sebanyak 1,711 dikeluarkan. ${ }^{39}$ Terdapat 
peningkatan tinggi tanah khasnya untuk tujuan perladangan di Kedah Selatan, dengan 93 permohonan tanah berkeluasan melebihi 50 relong (28,172 relong) dan 37 diluluskan (melibatkan 10,517 relong). Di Kedah Selatan 48 permohonan besar dan sembilan diterima $(1,410$ relong). ${ }^{40}$ Pada tahun 1335 Hijrah (1916-1917), jumlah permohonan tanah berkeluasan besar yang diluluskan ialah 175 melibatkan keluasan 23,000 relong. Kebanyakan tanah yang diluluskan ini terletak di Kedah Selatan. ${ }^{41}$

Pertambahan permohonan tanah mengakibatkan peningkatan beban kerja kedua-dua Jabatan Tanah dan Jabatan Ukur. Pada 1917, Supritendan Ukur memohon kepada MN untuk mendapatkan tiga orang Juru Ukur Eropah. MN yang menimbangkan permohonan ini meluluskan untuk melantik dua orang Juru Ukur Eropah. ${ }^{42}$ Dapat dirumuskan, pemberian pemilikan tanah di Kedah nyata tertumpu kepada pemberian pemilikan tanah berkeluasan besar untuk para pelabur. Pemberian tanah berkeluasan kecil kepada orang Melayu pula tidak berjalan dengan lancar. Permohonan tanah orang Melayu dalam kebanyakan kes mengambil masa bertahun-tahun untuk diproses. Akibatnya masih ramai orang Melayu yang menduduki tanah kerajaan tanpa pemilikan yang sah lebih-lebih lagi di daerah-daerah pedalaman.

\section{Pengutipan Hasil Tanah}

Satu elemen penting dalam mengukur keberkesanan pemodenan pentadbiran tanah Kedah adalah dengan melihat jumlah kutipan hasil tanah sepanjang tempoh 1909-1917. Sememangnya salah satu niat pihak British dalam usaha memperlengkap dan melicinkan jentera operasi Jabatan Tanah Kedah adalah untuk meningkatkan jumlah hasil tanah. Oleh itu, kejayaan mahupun kegagalan usaha ini boleh diterjemahkan dengan meneliti angka-angka hasil tanah negeri. Hasil tanah negeri ini merangkumi penjualan tanah, cukai tanah, yuran ukur, permit ladang, penjualan batu perenggan tanah, pembayaran pendaftaran dan pelbagai yuran dan cas.

Sejak 1909 lagi, hasil tanah membentuk bahagian yang besar daripada pendapatan keseluruhan Kerajaan Kedah. Didapati sejak tahun 1327 Hijrah (1909-1910) hingga tahun 1334 Hijrah (1915-1916), hasil tanah terus menerus membentuk komponen yang besar daripada pendapatan tahunan kerajaan. Bermula penguasaan British, hasil tanah direkodkan berjumlah $\$ 242,873$. Hasil tanah terus meningkat pada tahun 1328 Hijrah (1910) kepada \$398,034. Manakala pada tahun berikutnya iaitu 1329 Hijrah (1911), pendapatan tanah hanya menunjukkan peningkatan yang sangat kecil iaitu 399,649. Bagaimanapun, hasil tanah meningkat dengan mendadak pada tahun 1330 Hijrah (1911- 
1912) dengan jumlah $\$ 438,211$ direkodkan. Jumlah pendapatan yang diperolehi Kerajaan Kedah pada tahun tersebut adalah sebanyak $\$ 2,045,322$, lantas hasil tanah membentuk peratusan 21.4 peratus daripada keseluruhan pendapatan kerajaan. ${ }^{43}$

Jadual 1

Hasil Tanah Dan Pendapatan Kerajaan Kedah, 1327 Hijrah-1335 Hijrah (1909-1917)

\begin{tabular}{|l|c|c|}
\hline Tahun Hijrah & Hasil Tanah $(\$)$ & Pendapatan Kerajaan Kedah (\$) \\
\hline $1327(1909-1910)$ & 242,873 & $1,240,276$ \\
$1328(1910)$ & 398,034 & $1,449,116$ \\
$1329(1911)$ & 399,649 & $1,838,152$ \\
$1330(1911-1912)$ & 438,211 & $2,045,322$ \\
$1331(1912-1913)$ & 468,118 & $2,407,195$ \\
$1332(1913-1914)$ & 454,562 & $2,513,789$ \\
$1333(1914-1915)$ & 471,514 & $2,592,024$ \\
$1334(1915-1916)$ & 575,452 & $3,276,732$ \\
$1335(1916-1917)$ & 766,038 & $4,584,180$ \\
& & \\
\hline
\end{tabular}

Sumber: A.R.A.G.K. 1327 A.H.-1335 A.H. (1909-1917)

Lebih membanggakan lagi, antara Negeri-negeri Melayu di bawah penguasaan British, Kedah merupakan negeri ketiga tertinggi perolehan hasil tanahnya pada tahun 1912 iaitu sebanyak \$438,211 selepas Perak $(\$ 1,352,577)$ dan Selangor $(\$ 983,083)$. Dari segi peratusan perolehan hasil tanah daripada pendapatan keseluruhan negeri, Kedah menduduki tempat kedua sekiranya dibandingkan dengan Negeri-negeri Selat (NNS), NNMB dan Negeri-negeri Melayu Tidak Bersekutu yang lain iaitu sebanyak 21.4 peratus. Peratusan ini merupakan kedua tertinggi selepas Melaka yang mencatatkan 24.9 peratus. ${ }^{44}$ Jumlah hasil tanah terus meningkat apabila pada tahun 1331 Hijrah (1912-1913) )sebanyak $\$ 468,118$. Namun pada tahun 1332 Hijrah (1913-1914), pendapatan tanah merosot sedikit kepada \$454,562. Tahun 1333 Hijrah (1914-1915) menyaksikan peningkatan semula pendapatan tanah kepada $\$ 471,514$. Pendapatan tanah terus meningkat kepada $\$ 575,452$ pada tahun 1334 Hijrah (1915-1916) dan meningkat dengan begitu mendadak kepada jumlah \$766,038 pada tahun berikutnya iaitu 1335 Hijrah (1916-1917). Tunggakan cukai tanah dan sewa tanah pada tahun 1333 Hijrah (19141915) adalah sebanyak $\$ 143,761$. Tunggakan di Kedah Utara ialah $\$ 120,130$ dan di Kedah Selatan, \$23,631. Masalah tunggakan yang begitu besar di Kedah Utara sebenarnya disumbangkan oleh faktor mutu tugas 
Penghulu yang buruk dan kurang memberikan kerjasama kepada pihak Pejabat Tanah. Pihak Jabatan Tanah Kedah harus melepaskan tunggakan cukai tanah di Kedah Utara kerana tunggakan ini tidak dapat dilunaskan oleh penduduk. Pada tahun 1333 Hijrah (1914-1915) juga, buat pertama kalinya Kerajaan Kedah mendapat rekod tunggakan cukai tanah yang lengkap bagi Kedah Utara. ${ }^{45}$

Pada tahun 1335 Hijrah (1916-1917), usaha Jabatan Tanah bagi mengurangkan tunggakan cukai tanah berjalan lancar. ${ }^{46}$ Usaha-usaha pentadbiran tanah bagi memaksa pemilik tanah membayar cukai tanah jelas sekali tidak seimbang dengan pertambahan kecekapan kerja Pejabat-pejabat Tanah di seluruh Kedah. Bahkan kualiti kerja dalaman Jabatan Tanah sendiri tidak seimbang antara bahagian utara dan selatan. Kecenderungan Jabatan Tanah Kedah dalam memberikan fokus kepada pentadbiran di Kedah Selatan menimbulkan gejala ketidakseimbangan pentadbiran tanah yang serius antara Kedah Utara dan Kedah Selatan.

\section{Ketidakseimbangan Mutu Pentadbiran Tanah di Kedah Utara dan Kedah Selatan}

Pemodenan pentadbiran tanah Kedah telah mewujudkan suatu keadaan yang tidak seimbang antara Kedah Utara dan Kedah Selatan. Ketidakseimbangan ini wujud sejak akhir abad ke-19 dan diperjurangkan apabila pihak British dengan kerjasama MN memberikan perhatian yang berlebihan kepada Kedah Selatan. Ini menyaksikan perbezaan yang begitu besar dalam konteks pencapaian kedua-dua bahagian Kedah. Tumpuan besar yang diberikan oleh pihak pentadbiran tanah Kedah terhadap Kedah Selatan begitu nyata apabila pada tahun 1333 Hijrah (1914-1915), jumlah tanah berkeluasan kecil yang diberikan kerajaan di Bandar Baharu sahaja melebihi jumlah pemberian tanah di seluruh Kedah Utara. Kecekapan pentadbiran tanah di Kedah Selatan telah menyebabkan berakhirnya pengeluaran dokumen permit tanah pada 1333 Hijrah (1914-1915), sedangkan di Kedah Utara langkah yang dijalankan berhubung pengeluaran permit adalah sekadar mengehadkan pemberiannya. ${ }^{47}$ Manakala dalam aspek tunggakan cukai tanah, tunggakan di Kedah Selatan hampir terhapus sedangkan di Kedah Utara pula tunggakan cukai tanah semakin berkurangan. ${ }^{48}$

Ketidakseimbangan mutu kerja antara pentadbiran tanah di Kedah Utara dan Kedah Selatan merupakan isu yang menjadi kebimbangan pihak British. Misalnya pada tahun 1334 Hijrah (1915-1916), menyentuh isu mutu kerja Pejabat-pejabat Tanah, Penasihat Tanah menyebut tugas kakitangan Kepala Pekerjaan Tanah di Alor Star bersikap acuh tidak acuh dalam menjalankan tanggungjawab dan berlaku pembaziran masa. ${ }^{49}$ Ini begitu berbeza dengan keadaan di Kedah Selatan kerana 
apabila Penasihat Tanah ditempatkan, mutu kerja yang ditonjolkan adalah baik. Ulasan bernada sungutan dilemparkan Pemangku Penasihat British, G.A. Hall pada tahun 1334 Hijrah (1915-1916) yang menyebut seorang sahaja pegawai tanah Eropah tidak akan mampu memantau dan menyelia keseluruhan Pejabat Tanah di seluruh Negeri Kedah. Memetik ulasan G.A. Hall beliau menyatakan dengan jelas: "Until at least one more European Land Officer can be obtained to supervise North Kedah, there is little hope of improvement." ${ }^{0}$ Paradoks kepada sungutan pihak British berhubung ketidakseimbangan mutu kerja di kedua-dua bahagian Kedah ini ialah pihak British sendiri tiada usaha secara bersungguh-sungguh untuk memperbetulkan keadaan. Pentadbiran tanah Kedah yang didalangi British jelas memberikan tumpuan besar kepada Kedah Selatan. Ini kerana daerah-daerah di bahagian selatan negeri tersebut mendatangkan pulangan pendapatan yang lebih besar kepada perbendaharaan negeri. Bersandarkan kepada jumlah kutipan cukai tanah yang lebih besar jumlahnya di Kedah Selatan, pasti kutipannya datang daripada para pelabur yang berkuku di Kedah Selatan.

Kedah Utara yang merupakan kawasan yang dominan Melayu, menyumbang jumlah kutipan cukai tanah yang lebih rendah daripada bahagian selatan. Pada tempoh 1909-1917, masih banyak pemilikan tanah orang Melayu di Kedah Utara yang belum direkodkan. Ini mendatangkan kesan negatif dalam aspek pencukaian apabila pencukaian tanah yang lengkap tidak dapat dijalankan ditambah pula dengan kewujudan pemilikan tanah yang besar oleh elit Melayu di bahagian utara Kedah. Daripada nilai pelepasan cukai sebanyak \$19,774 yang buat pertama kalinya dan direkodkan secara lengkap pada tahun 1333 Hijrah (1914-1915), didapati sejumlah \$16,392 merupakan nilai pelepasan cukai tanah di Kedah Utara. ${ }^{51}$ Ini menunjukkan taburan pemilikan tanah golongan Kerabat Diraja dan elit Melayu Kedah sememangnya tertumpu di kawasan Kedah Utara. ${ }^{52}$ Kekurangan pelaburan dan kecekapan kerja Jabatan Tanah di bahagian Kedah Utara telah menyumbang kepada penghasilan jumlah kutipan lebih kecil daripada Kedah Selatan.

\section{Kesimpulan}

Penguasaan British keatas Kedah pada 1909 menyaksikan perkembangan yang pesat berlaku kepada pentadbiran tanahnya. Melalui inisiatif MN, Jabatan Tanah Kedah selaku birokrasi pentadbiran tanah Kedah telah mendapat sentuhan Penasihat Tanah Eropah dalam merencana dan menjalankan pemodenan pentadbiran dan perundangan. Dapat dirumuskan bahawa pentadbiran tanah Kedah telah melalui proses 
pemodenan yang sangat memberangsangkan. Walaupun terdapat cacat cela dalam reformasi pentadbiran, harus diakui Jabatan Tanah Kedah sebenarnya berjaya berkembang dengan maju dalam tempoh yang begitu singkat, 1909-1917. Peranan yang dimainkan Jabatan Tanah ini telah membawa kepada perubahan amalan dan sistem tanah tradisional orang Melayu Kedah kepada sistem yang moden. Sebaliknya, usahausaha yang dijalankan Kerajaan Kedah dan Jabatan Tanah, nyata sekali bermotif bagi menambah pendapatan kerajaan negeri melalui kutipan hasil tanah.

Selain itu, pemodenan yang berlaku lebih menguntungkan golongan pelabur asing yang melihat keberkesanan pentadbiran dan perundangan tanah Kedah sebagai jaminan sekuriti kepada modal yang dilaburkan mereka, khasnya dalam konteks pertanian komersial. Tumpuan pemodenan pentadbiran tanah Kedah juga nyata lebih ditumpukan di Kedah Selatan, kawasan yang menjadi tumpuan utama golongan pemodal. Ini secara langsung menyebabkan kawasan Kedah Selatan lebih menikmati pembangunan fizikal yang jauh lebih pesat berbanding Kedah Utara. Polarisasi yang terbentuk antara Kedah Utara dan Kedah Selatan kesan pembangunan pentadbiran tanah yang tidak seimbang dalam tempoh ini lantas menimbulkan keadaan yang boleh disifatkan sebagai ‘Kedah Utara untuk orang Melayu manakala Kedah Selatan untuk pelaburan asing'. Oleh itu, reformasi pentadbiran tanah yang berlangsung dengan pesat dalam jangka masa sembilan tahun ini tidak memberikan faedah yang setara kepada semua pihak.

\section{Nota}

1 C.O. 716, Kedah Perlis Sessional Papers. The Annual Report of The Adviser To The Kedah Government For The Year (A.R.A.K.G.) 1327 A.H. (23 ${ }^{\text {rd }}$ January, 1909-12 ${ }^{\text {th }}$ January, 1910), Kuala Lumpur: F.M.S. Government Printing Office, 1910, hlm. 62.

2 H. E. Wilson, "The Evolution of Land Administration in the Malay States: A Survey of British-Inspired Changes", Journal of the Malaysian Branch of the Royal Asiatic Society, 48 (1), (1975), hlm. 128.

3 Ahmad Nazri Abdullah, Melayu dan Tanah, Petaling Jaya: Media Intelek Sdn. Bhd., 1985, hlm. 13.

$4 \quad$ "Kepala Pekerjaan Tanah" ialah istilah rasmi yang digunakan Kerajaan Kedah di era kolonial untuk merujuk kepada Pengarah Tanah (Director of Lands).

C.O. 716, Kedah Perlis Sessional Papers. A.R.A.K.G. 1327 A.H., hlm. 19.

Ibid., hlm. 21.

Ibid., hlm. 28.

Ibid., hlm. 22.

Peter Dorner, Land Reform and Economic Development, Middlesex: Penguin Bookd Ltd., 1972, hlm. 18. 
Mohd. Isa Othman, Pengalaman Kedah E Perlis Zaman Penjajahan British, Kuala Lumpur: Utusan Publications \& Distributors Sdn. Bhd., 2001, hlm. 126.

11 C.O. 273/375/35581, Kedah State Council, 6 ${ }^{\text {th }}$ Shaaban 1329 (2 August 1911). Memorandum by the Adviser to Accompany the Minutes of the Council Meeting of the $22^{\text {nd }}$ August 1911.

C.O. 716, Kedah Perlis Sessional Papers. A.R.A.K.G. 1327 A.H., hlm. 19.

13 Ibid., hlm. 20.

$14 \quad$ Ibid., hlm. 20-21.

Mohd. Isa Othman, Pengalaman Kedah \& Perlis Zaman Penjajahan British, hlm. 127.

C.O. 716, Kedah Perlis Sessional Papers. A.R.A.K.G. 1327 A.H., hlm. 21.

Ibid., hlm.21.

18 C.O. 716, Kedah Perlis Sessional Papers. A.R.A.K.G. 1329 A.H. (2 ${ }^{\text {nd }}$ January$21^{\text {st }}$ December, 1911), hlm. 6.

C.O. 716, Kedah Perlis Sessional Papers. A.R.A.K.G. 1328 A.H., hlm. 9.

Ibid., hlm. 10.

Ibid.

Berbanding dengan Jabatan Tanah, Jabatan Ukur mempunyai lebih ramai kakitangan berbangsa Eropah dan asing. Ini kerana Jabatan Ukur memerlukan tenaga manusia yang berkemahiran tinggi dalam penggunaan alatan moden. Dapat dilihat dengan jelas, Jabatan Ukur pada tahun 1912-1913 mengandungi lima orang pegawai bangsa Eropah di samping enam penolong Juru Ukur, lima kadet Juru Ukur, tujuh orang Computers dan Draftsmen, lapan orang kadet Draftsmen dan dua orang Pengesan. Jabatan Ukur sangat mementingkan mutu kerja dan berusaha dari masa ke masa meningkatkan kecekapan kakitangannya. Dapat dilihat sistem kadet juru ukur yang dijalankan kepada anak-anak Melayu di Jabatan Ukur mendatangkan hasil yang sangat memberangsangkan. Pada 1912-1913, dua orang kadet Melayu Kedah menjadi Penolong Juru Ukur yang berkelayakan. Lihat C.O. 716, Kedah Perlis Sessional Papers. A.R.A.K.G. 1331 A.H. (11 ${ }^{\text {th }}$ December, 1912-30 ${ }^{\text {th }}$ November, 1913), hlm. 4-5. Satu relong bersamaan dengan 0.71 ekar. C.O. 716, Kedah Perlis Sessional Papers. A.R.A.K.G. 1329 A.H., hlm. 4-5. C.O. 273/385/14379. Kedah State Council, $26^{\text {th }}$ Rabialawal 1330 Hijrah. C.O. 273/375/35581, Kedah State Council. Translation of the Minutes of a Meeting of the State Council Held On the $6^{\text {th }}$ Ramathan $1329\left(31^{\text {st }}\right.$ August 1911). C.O. 716, Kedah Perlis Sessional Papers. A.R.A.K.G. 1327 A.H., hlm. 18. C.O. 273/385/9767. Kedah State Council, 18 Muharram 1330 Hijrah. Penolong Kepala Pekerjaan Tanah Kedah Selatan ini mempunyai kuasa seperti Kepala Pekerjaan Tanah dan bertanggungjawab terus terhadap Presiden MN.

$30 \quad$ Enakmen Tanah 1332 (The Land Enactment No. 7 of 1332) diluluskan oleh MN pada 8 Jun 1914, tetapi ditandatangani Pemangku Raja pada 17 Oktober 1914. Ini kerana beberapa perubahan dilakukan berkaitan 
soal pengecualian cukai tanah terhadap Kerabat Diraja. Perubahan yang dipersetujui menjadi Enakmen No. 15 Tahun 1332 Hijrah (1914) yang meminda dan memperbaharui Land Exemptions Enactment 1331 dengan pindaan-pindaan.

Menurut Salleh Buang, prinsip pertama Sistem Torrens ialah daftar yang mencerminkan segala fakta material berhubung hak milik seseorang ke atas tanahnya. Prinsip kedua pula ialah kewujudan daftar yang mempunyai sifat 'tabir'. Dalam hal ini, setiap transaksi antara pemilik berdaftar dengan bakal pembeli, bakal pembeli hanya perlu memberikan perhatian kepada daftar dan tidak lebih daripada itu. Untuk melihat prinsip Sistem Torrens, sila lihat Salleh Buang, Undang-undang Tanah di Malaysia, Kuala Lumpur: Dewan Bahasa Dan Pustaka, 1993. Sebenarnya Kedah cuba mengikut Sistem Torrens sebelum tahun 1909 lagi, namun usaha ini digagalkan oleh golongan elit tradisional. C.O. 273/426. Kedah Enactments 7-16 A.H. 1332.

Kadar 60 sen serelong dikenakan setiap tahun bagi tanah bendang, kampung dan dusun. Manakala $\$ 1.50$ perlu dijelaskan bagi pemilik tanah getah, kelapa dan tanaman komersial yang lain. C.O. 716, Kedah Perlis Sessional Papers. A.R.A.K.G. 1332 A.H. (30 ${ }^{\text {th }}$ November, 1913-18 ${ }^{\text {th }}$ November, 1914), hlm. 4. Ibid.

Ibid., hlm. 5 .

C.O. 716, Kedah Perlis Sessional Papers. A.R.A.K.G. 1331 A.H., hlm. 3.

C.O. 716, Kedah Perlis Sessional Papers. A.R.A.K.G. 1332 A.H., hlm. 3-4. Ibid., hlm. 3.

C.O. 716, Kedah Perlis Sessional Papers. A.R.A.K.G. 1334 A.H. (9 $9^{\text {th }}$ November, 1915-27 $7^{\text {th }}$ October, 1916), hlm. 2.

C.O. 273/460/44923. Kedah State Council, 21 ${ }^{\text {st }}$ May 1917.

C.O. 716, Kedah Perlis Sessional Papers. A.R.A.K.G. 1331 A.H., hlm. 4.

Ibid., hlm. 2.

C.O. 716, Kedah Perlis Sessional Papers. A.R.A.K.G. 1333 A.H., hlm. 2.

C.O. 716, Kedah Perlis Sessional Papers. A.R.A.K.G. 1335 A.H. $\left(28^{\text {th }}\right.$ October, 1916-17 ${ }^{\text {th }}$ October, 1917), hlm. 1.

C.O. 716, Kedah Perlis Sessional Papers. A.R.A.K.G. 1333 A.H. (19

November, 1914-8 $8^{\text {th }}$ November, 1915), hlm. 2.

C.O. 716, Kedah Perlis Sessional Papers. A.R.A.K.G. 1334 A.H., hlm. 2.

49 Ibid.

$50 \quad$ Ibid., hlm. 3.

51 C.O. 716, Kedah Perlis Sessional Papers. A.R.A.K.G. 1333 A.H., hlm. 2.

$52 \quad$ C.O. 716, Kedah Perlis Sessional Papers. A.R.A.K.G. 1334 A.H., hlm. 2. 